\title{
University food environment: characterization and changes from 2011 to 2016 in a Brazilian public university
}

\section{Ambiente alimentar universitário: caracterização \\ e mudanças no período de 2011 a $2016 \mathrm{em}$ \\ uma universidade pública brasileira}

\author{
Amanda da Silva FRANCO ${ }^{1}$ [D] 0000-0003-2155-1381 \\ Daniela Silva CANELLA² (ID) 0000-0001-9672-4983 \\ Patrícia Maria Périco PEREZ ${ }^{2}$ [D] 0000-0002-9849-5587 \\ Daniel Henrique BANDON|3 ${ }^{3}$ 0000-0003-1638-1437 \\ Inês Rugani Ribeiro de CASTRO4 [D. 0000-0002-7479-4400
}

A B S T R A C T

\section{Objective}

To describe the food environment of a public university located in the city of Rio de Janeiro, Brazil, and to review the changes that occurred between the years 2011 and 2016.

\section{Methods}

Time trend study (through repeated cross-sectional studies) of the sale of food, culinary preparations and beverages in the University Campus establishments in 2011, 2012 and 2016. Variables regarding the description

1 Faculdade Bezerra de Araújo, Coordenação de Pós-Graduação e Extensão, Curso de Nutrição. R. Carius, n. 206, Campo Grande, 23052-180, Rio de Janeiro, RJ, Brasil. Correspondence to: A. S. FRANCO. E-mail: <franco.amandarj@gmail.com>.

2 Universidade do Estado do Rio de Janeiro, Instituto de Nutrição, Departamento de Nutrição Aplicada. Rio de Janeiro, RJ, Brasil.

3 Universidade Federal de São Paulo, Instituto de Saúde e Sociedade, Departamento de Saúde, Clínica e Instituições. Santos, SP, Brasil.

${ }^{4}$ Universidade do Estado do Rio de Janeiro, Instituto de Nutrição, Departamento de Nutrição Social. Rio de Janeiro, RJ, Brasil.

The manuscript was elaborated from the thesis by A. S. Franco, entitled "University food environment: characterization, quality of measurement and change in time". Universidade do Rio de Janeiro; 2016.

How to cite this article

Franco AS, Canella DS, Perez PMP, Bandoni DH, Castro IRR. University food environment: characterization and changes from 2011 to 2016 in a Brazilian public university. Rev Nutr. 2020;33:e200058. https://doi.org/10.1590/1678-9 $865202033 e 200058$ 
of the establishments and the offer, price and advertising of food, beverages and culinary preparations were assessed through a checklist. Comparisons between establishments in each year and the analysis of such comparison changes during the period were performed by assessing the difference between absolute and relative values observed in each year.

\section{Results}

Increased number of establishments available, good convenience and financial accessibility were observed. There was a relative disadvantage in the availability of fresh or minimally processed foods and culinary preparations; a predominance of advertising of ultra-processed foods; and lack of nutritional information of culinary preparations. The predominance of establishments selling snacks and candies increased over the years.

\section{Conclusion}

In the period studied, the university food environment did not favor healthy food choices.

Keywords: Food and nutrition security. Food services. University.

\section{RE S U M O}

\section{Objetivo}

Descrever o ambiente alimentar de uma universidade pública localizada na cidade do Rio de Janeiro e analisar as mudanças nele ocorridas no período de 2011 a 2016.

\section{Métodos}

Estudo de tendência temporal (por meio de estudos transversais repetidos) da comercialização de alimentos, preparações e bebidas nos estabelecimentos existentes dentro do campus em 2011, 2012 e 2016. Foram examinadas, por meio de checklist, variáveis referentes à descrição dos estabelecimentos e a oferta, preço e propaganda de alimentos, bebidas e preparações. A comparação entre os estabelecimentos e a análise das variações verificadas no período foi realizada com base no exame das diferenças entre valores absolutos e relativos observadas em cada ano.

\section{Resultados}

Foram observados aumento da disponibilidade de estabelecimentos, boa comodidade e acessibilidade financeira. Verificou-se desvantagem relativa da disponibilidade de alimentos in natura ou minimamente processados e de preparações, predominância de propaganda de alimentos ultraprocessados e ausência de informações nutricionais das preparações. A predominância de estabelecimentos que comercializavam lanches e guloseimas se acentuou no período.

\section{Conclusão}

No período estudado, o ambiente alimentar universitário não favoreceu escolhas alimentares saudáveis.

Palavras-chave: Segurança alimentar e nutricional. Serviços de alimentação. Universidade.

\section{NTRODUCTION}

The organizational food environments influence the eating habits of the individuals who attend such places [1-3]. Among them, the University Food Environment (UFE) exhibited a few specificities: it is an education and work center, its student community is made up of young people for whom college admission often coincides with taking responsibility for their housing, food, managing their finances and time. It brings together teaching, research and extension activities, and can experience new models of organization, including in relation to the food environment, and serve as a sounding board for these models for other institutions and for the drawing of public policies [4].

The study objective was to describe the food environment of a university located in the city of Rio de Janeiro and to review the changes that occurred in the period from 2011 to 2016, taking 
into account the importance and specificities of the UFE, the scarcity of research characterizing these environments in Brazil and the lack of studies that monitor their dynamics over time. In addition to contributing to the understanding of this food environment, this study brings a pioneering contribution, which is to examine changes in this environment during a given period $[5,6]$. Understanding the dynamics of the food environment over time allows us to understand the changes in the exposure of students and workers to factors that influence eating practices and can support interventions to improve them.

\section{METHODS}

This is a time trend study (comparing repeated cross-sectional studies) of the food environment of a public university, carried out in the city of Rio de Janeiro. The university surveyed has 11 campuses. The investigation was conducted in the largest of them, a urban, vertical campus, 12 floor tall-building, where approximately 35,000 people circulate daily and courses are offered in the areas of Technology and Sciences, Health, Social Sciences and Education and Humanities which activities take place from $7 \mathrm{am}$ to $11 \mathrm{pm}$ and, in some of them, also on Saturdays.

Data collection was carried out by previously trained evaluators in November and December 2011, 2012 and 2016. The 2012 evaluation aimed to record any changes in the UFE resulting from the opening of the University Restaurant (UR), which took place late 2011, and that of 2016 aimed at the monitoring of this environment. An audit was carried out in all the establishments that sold food, culinary preparations and beverages within the campus, using a structured checklist instrument. This method was chosen because it facilitates monitoring, over time, of simplified indicators for the characterization of food environments.

The following were considered: availability (existence of food outlets and food supply), financial accessibility (assuming prices as Proxy), convenience (days and opening hours compatible with the courses activities), nutritional information and food promotion $[7,8]$. The checklist used in the 2011 and 2012 data collections was adapted from the checklist developed and validated by Duran et al. [9] incorporating items that covered the dimensions mentioned above. In 2016, a modified version of this checklist was applied and its content validity and reproducibility were evaluated [10].

Bearing in mind that the instruments used in the three years of survey were not identical, to characterize the UFE and analyze their dynamics over time, the variables and indicators examined are those that are comparable, namely: (a) description of establishments: number of food outlets; proportion of establishments according to: type, day and opening hours (the categories of these variables are detailed in Table 1); (b) characterization of food offer, culinary preparations and beverages: proportion of food outlets that provided snacks, buffet and/or standard dish; vegetables as hot dishes and/or as side dishes; exclusive dishes with fruits and vegetables; fresh or prepared natural juices from pulp; fruit salad or fresh fruit for dessert; half portion or reduced portions of food; fried or baked snacks, sandwiches or crepes; replacement of French fries in standard dishes or "combos" (sandwich with side food and/or beverage) with salad or cooked vegetables; option of substituting rice in standard dish with brown rice; option to replace soda from "combos"/promotions with natural juices; "combo"/promotion with final price lower than the sum of the price of each component; larger portion with price increase proportionally lower than the value of the original portion; and ultra-processed foods and beverages [11]; (c) price of the items: lowest and highest prices of food/meals, ultra-processed beverages, fruit juice, dessert and items from the candy stand; 
(d) advertisements: establishments with advertisements for healthy food or beverages (fruit, fruit salad, natural fruit juice or salads) and unhealthy (ultra-processed beverages, dessert and/or ice cream).

Table 1. Characterization of establishments selling food, culinary preparations and drinks at the university by year of study. Rio de Janeiro (RJ), Brazil, 2011-2016.

\begin{tabular}{|c|c|c|c|c|c|c|}
\hline \multirow{3}{*}{ Characteristics } & \multicolumn{6}{|c|}{ Year } \\
\hline & \multicolumn{2}{|c|}{$2011(n=15)$} & \multicolumn{2}{|c|}{$2012(n=17)$} & \multicolumn{2}{|c|}{$2016(n=25)$} \\
\hline & $\%$ & $\mathrm{n}$ & $\%$ & $n$ & $\%$ & $\mathrm{n}$ \\
\hline \multicolumn{7}{|l|}{ Establishment type } \\
\hline Restaurant by dish weight or a la carte & 6.6 & 1 & 11.8 & 2 & 4.0 & 1 \\
\hline Snack bar (fast food) & 46.7 & 7 & 58.8 & 10 & 52.0 & 13 \\
\hline Mixed (restaurant and snack bar) & 46.7 & 7 & 29.4 & 5 & 34.0 & 9 \\
\hline Bomboniere (candy stand) & 0.0 & 0 & 0.0 & 0 & 10.0 & 2 \\
\hline \multicolumn{7}{|l|}{ Days of Operation } \\
\hline Monday to Friday & 86.7 & 13 & 76.5 & 13 & 84.0 & 21 \\
\hline Monday to Saturday & 13.3 & 2 & 23.5 & 4 & 16.0 & 4 \\
\hline \multicolumn{7}{|l|}{ Opening Hours } \\
\hline Lunch & 6.6 & 1 & 5.9 & 1 & 4.0 & 1 \\
\hline Lunch and dinner & 0.0 & 0 & 5.9 & 1 & 4.0 & 1 \\
\hline Morning, afternoon and night & 93.4 & 14 & 88.2 & 15 & 92.0 & 23 \\
\hline
\end{tabular}

The indicators presented were developed for the total number of food outlets in each of the three years of the study. The data analysis covered the comparison between establishments, in each year and between the years of study. This was done based on the description of the difference between the proportions observed at each time of the assessment. For the comparison between prices, the ratio between the highest and lowest prices observed in the group of establishments was calculated for each item analyzed in each separate year.

The database was built using the Epi Info 6.04 program and the data were processed using the Statistical Package for the Social Sciences (SPSS) $[12,13]$.

This study was approved by the Research Ethics Committee of the university (opinion 1.320.075). All existing establishments agreed to participate and gave permission for observation and data collection.

\section{RE S U L T S}

A total of 15, 17 and 25 establishments were evaluated in 2011, 2012 and 2016 respectively, with at least one establishment per floor of the building. In the three years, almost all establishments operated in three shifts and some of them, also on Saturdays. Those that sold snacks and sweets (snack bars, candy stand and mixed establishments) predominated when compared to those that sold meals (restaurants and mixed food outlets) (Table 1). No establishment that commercialized culinary preparations provided nutritional information about them.

Given that the large majority of establishments that sold snacks and sweets increased over the years, even though there was an increase in the number of establishments that sold fruits or vegetables, their relative importance in the UFE decreased. In addition, it is noteworthy that all food 
outlets sell ultra-processed beverages and practically all, treats, regardless of the type of establishment and the year of study (Table 2). Energy drinks, which were not offered in any establishment in 2011, were sold by 58\% of the food outlets in 2012 and by 52\% of them in 2016 (data not shown).

Table 2. Characterization of food supply in commercial establishments at the university by year of study. Rio de Janeiro (RJ), Brazil, 2011-2016.

\begin{tabular}{|c|c|c|c|c|c|c|}
\hline \multirow{3}{*}{ Food Availability } & \multicolumn{6}{|c|}{ Year } \\
\hline & \multicolumn{2}{|c|}{$2011(n=15)$} & \multicolumn{2}{|c|}{$2012(n=17)$} & \multicolumn{2}{|c|}{$2016(n=25)$} \\
\hline & $\%$ & $\mathrm{n}$ & $\%$ & $\mathrm{n}$ & $\%$ & $\mathrm{n}$ \\
\hline \multicolumn{7}{|l|}{ Type of Culinary Preparation } \\
\hline Snacks & 93.3 & 14 & 88.2 & 15 & 88.0 & 22 \\
\hline Fried or roasted snacks & 93.3 & 14 & 82.4 & 14 & 72.0 & 18 \\
\hline Sandwich or crepes & 86.7 & 13 & 82.4 & 14 & 80.0 & 20 \\
\hline Meal by weight & 26.7 & 4 & 23.5 & 4 & 20.0 & 5 \\
\hline Standard dish & 33.3 & 5 & 35.3 & 6 & 16.0 & 4 \\
\hline \multicolumn{7}{|l|}{ Offer of Fruits and Vegetables } \\
\hline Vegetables & 46.7 & 7 & 47.1 & 8 & 36.0 & 9 \\
\hline Fruits & 40.0 & 6 & 47.1 & 8 & 24.0 & 6 \\
\hline Juices & 66.7 & 10 & 58.8 & 10 & 44.0 & 11 \\
\hline Fruits or vegetables & 53.3 & 8 & 58.8 & 10 & 44.0 & 11 \\
\hline Fruits and juices & 40.0 & 6 & 41.2 & 7 & 16.0 & 4 \\
\hline Fruits and vegetables & 33.3 & 5 & 35.3 & 6 & 16.0 & 4 \\
\hline Fruits and juices and vegetables & 33.3 & 5 & 29.4 & 5 & 8.0 & 2 \\
\hline Fruits or juices or vegetables & 73.3 & 11 & 70.6 & 12 & 56.0 & 14 \\
\hline \multicolumn{7}{|l|}{ Ways of offering Fruits and Vegetables } \\
\hline As hot dishes ${ }^{1}$ & 20.0 & 3 & 23.5 & 4 & 32.0 & 8 \\
\hline Among those offering FV & 42.9 & 3 & 50.0 & 4 & 88.9 & 8 \\
\hline As side dish ${ }^{2}$ & 33.3 & 5 & 41.2 & 7 & 20.0 & 5 \\
\hline Among those offering $\mathrm{FV}$ & 71.4 & 4 & 87.5 & 7 & 55.6 & 5 \\
\hline Exclusive dishes with FV & 26.7 & 4 & 35.3 & 6 & 32.0 & 8 \\
\hline Among those offering FV & 57.1 & 4 & 75.0 & 6 & 88.9 & 8 \\
\hline Fresh or prepared natural juices from frozen pulp & 66.7 & 10 & 58.8 & 10 & 44.0 & 11 \\
\hline Fruit salad or fresh fruit as dessert & 40.0 & 6 & 47.1 & 8 & 24.0 & 6 \\
\hline \multicolumn{7}{|l|}{ Offering of bomboniere items } \\
\hline Candies (drops, sweets, etc.) & 93.3 & 14 & 88.2 & 15 & 84.0 & 21 \\
\hline Ultra-processed drinks ${ }^{3}$ & 100.0 & 15 & 100.0 & 17 & 100.0 & 25 \\
\hline Cereal Bars & 80.0 & 12 & 70.6 & 12 & 44.0 & 11 \\
\hline Stuffed sweet biscuit & 80.0 & 12 & 82.4 & 14 & 68.0 & 17 \\
\hline Sweet biscuit without filling & 86.7 & 13 & 76.5 & 13 & 68.0 & 17 \\
\hline Packet snacks & 66.7 & 10 & 64.7 & 11 & 80.0 & 20 \\
\hline Whole grain cookies & 60.0 & 9 & 35.3 & 6 & 28.0 & 7 \\
\hline $\begin{array}{l}\text { Other Sweets }^{4} \\
\text { Promotions }\end{array}$ & 86.7 & 13 & 100.0 & 17 & 84.0 & 21 \\
\hline Increased portion size ${ }^{5}$ & 0.0 & 0 & 5.9 & 1 & 8.0 & 2 \\
\hline $\begin{array}{l}\text { Promotion/combo } \\
\text { Healthy substitutions }\end{array}$ & 60.0 & 9 & 52.9 & 8 & 52.0 & 13 \\
\hline $\begin{array}{l}\text { French fries from standard dishes /combos for } \\
\text { salad or cooked vegetables }\end{array}$ & 20.0 & 3 & 0.0 & 0 & 8.0 & 2 \\
\hline Dishes made from rice/brown rice promotions & 6.7 & 1 & 0.0 & 0 & 0.0 & 0 \\
\hline Soda from combos/promotions of natural juices & 6.7 & 1 & 5.9 & 1 & 4.0 & 1 \\
\hline Half or reduced portions & 13.3 & 2 & 7.6 & 3 & 28.0 & 7 \\
\hline
\end{tabular}

Note: ${ }^{1}$ Composed exclusively of vegetables served hot; ${ }^{2}$ Vegetables served as side dishes with protein-based dishes; ${ }^{3}$ Includes industrialized juices, iced teas, natural guarana and soda; ${ }^{4} \mathrm{Cake}$, honey bread, sugary breakfast cereal; ${ }^{5}$ Price increase proportionally less than the value of the original portion; ${ }^{6}$ Final price lower than the sum of the prices of each component.

FV: Fruits and Vegetables. 
Although the supply of combos has slightly diminished in percentage terms, it has increased in absolute figures. Over the years, the promotion of larger portion size was observed. On the other hand, among the healthy replacements, the absolute and relative increase of the number of establishments offering the option of reduced portions is worth mentioning (Table 2).

Comparison between the lowest prices charged in the food outlets revealed that, in the three years of survey, fresh or minimally processed foods and culinary preparations were more expensive than unhealthy foods. The following item prices revealed a significant relative increase (of at least $50 \%$ ) during the period: meal by weight, sandwich, fruit juice and fruit (portion or fruit salad). On the other hand, there was a significant decrease $(55 \%)$ in the price of the standard dish due to the implementation of the UR in 2012. It is also noteworthy the increase in the ratio between the highest and lowest price of the standard dish in 2011 (1.8) compared to 2016 (8.0). This can be explained by the implementation of the UR associated with the significant increase in the value of this item in the higher priced restaurant. Also worth mentioning is the leveling of prices for the meal weight: while, in 2011, in the highest priced establishment, the kilo of the meal was 1.3 times the value of the lowest priced outlet, in 2016, in the highest and lowest priced food outlets meals by weight were practically the same (Table 3 ).

In relation to food advertising, the items that were most promoted were ultra-processed drinks, desserts and/or ice cream. Among the establishments that marketed these products, the proportion of the advertisement of these items ranged from $40.0 \%$ in 2011 to $90.1 \%$ in 2016. In the three years concerned, the advertisement of fruits, salads, natural juices and/or pulp products varied from $27.2 \%$ in 2011 to $18.2 \%$ in 2016 in those outlets that marketed such foods. It is also worth noting that, in all the establishments that started selling energy drinks on campus, ostentatious advertisements for these products were on display (results not shown).

Table 3. Prices, in reais (R\$), of food, culinary preparations and drinks offered at commercial establishments at the university by year of study. Rio de Janeiro (RJ), Brazil, 2011-2016.

\begin{tabular}{|c|c|c|c|c|c|c|}
\hline \multirow{2}{*}{ Items } & \multicolumn{3}{|c|}{ Lowest price observed in establishments } & \multicolumn{3}{|c|}{ Highest price observed in establishments } \\
\hline & 2011 & 2012 & 2016 & 2011 & 2012 & 2016 \\
\hline \multicolumn{7}{|l|}{ Food and culinary preparations } \\
\hline Standard dish & 4.49 & 2.00 & 2.00 & 8.00 & 15.00 & 16.00 \\
\hline Meal by weight & 23.90 & 28.90 & 39.90 & 29.89 & 32.89 & 40.90 \\
\hline Sandwich & 2.00 & 1.79 & 3.00 & 4.00 & 4.49 & 7.50 \\
\hline Fried salted/roasted & 1.79 & 2.00 & 1.80 & 3.49 & 3.60 & 6.00 \\
\hline Portion of French fries ${ }^{1}$ & 2.00 & 2.00 & 4.00 & 5.00 & 7.00 & 10.00 \\
\hline \multicolumn{7}{|l|}{ Drinks } \\
\hline Fruit Juice ${ }^{2}$ & 2.00 & 2.49 & 3.00 & 4.00 & 4.00 & 5.90 \\
\hline Regular soda & 2.49 & 2.70 & 2.00 & 3.00 & 3.49 & 5.00 \\
\hline Soft drink or iced tea ${ }^{3}$ & 0.70 & 0.70 & 1.00 & 2.00 & 1.49 & 3.50 \\
\hline \multicolumn{7}{|l|}{ Desserts } \\
\hline Portion of fresh fruits or fruits salad & 3.00 & 2.50 & 4.50 & 5.49 & 6.00 & 5.50 \\
\hline Sweeties $^{4}$ & 2.00 & 2.00 & 1.50 & 4.00 & 4.89 & 5.00 \\
\hline Bomboniere item 5 & 0.15 & 0.15 & 0.10 & 2.00 & 2.00 & 3.00 \\
\hline
\end{tabular}

Note: ${ }^{1}$ Portion prices (price per weight not included); ${ }^{2}$ Fresh natural juice and juice prepared from frozen pulp; ${ }^{3}$ Includes matte and natural guarana; ${ }^{4}$ Pies, mousses, jellies, etc. ${ }^{5}$ Candies, chocolates, peanut candy, etc. 


\section{DISCUSSION}

The results indicate an increase in the number of establishments that sell food at the university during the period studied, with convenient schedules (most of them worked three shifts and some of them, on Saturdays, following the extended operation hours of the university) and good food availability (in view of the prices charged), which, in the case of full meals, is now ensured by the UR. Factors that may negatively influence dietary practices were: the relative disadvantage of the availability of fresh or minimally processed foods and culinary preparations based on these foods and the predominance of ultra-processed food advertising (which encourages unhealthy choices); and, further, the lack of nutritional information on culinary preparations (which favors less informed choices).

Our results converge with those of other studies that indicate: predominance of supply and presence of unhealthy food advertising and relative disadvantage of healthy food prices, when available $[1,5,6,14]$. A systematic review of strategies for modifying the food environment showed that the most effective initiatives for improving college students' eating practices were: information reporting healthy foods claims; increase in the supply of these foods and reduction of the portion size; financial incentives and increased supply of healthy food combined with nutritional information [2].

Considering the university environment as a strategic space for the promotion of healthy eating and food and nutrition security, within the Brazilian framework, the relevance of this setting has become even greater since the incorporation of affirmative actions aimed at social inclusion [15]. In this connection, the existence of university restaurants is fundamental, as shown in a study carried out at this same university, which found an association between greater attendance to the UR and greater frequency of regular consumption of beans, vegetables and fruits and less substitution of dinners for snacks. Even so, the consumption of these foods was less than desirable and that of ultraprocessed foods was frequent [16].

These results show the importance of the UR in the university framework, and, at the same time, the need to develop other actions in the UFE. In order for UFE fully promote healthy eating to ensure food and nutrition security, it is necessary to make food positioning in the university's agenda more strategic. This means: improving the quality of food and beverages offered at the university's food outlets; investing in infrastructure for finishing of meals brought from home; ensuring easy access to drinking water; in the curricular arrangements ensuring sufficient time for meals; and in fostering healthy eating initiatives by the college decision-makers [4].

Weak points of this study include the fact that the instrument has undergone changes over the years of survey and lacks the performance evaluation of the first two years. However, those weak points were circumvented with the assessment carried out in 2016, which showed good reproducibility of the instrument and using only comparable items in the three years [10]. Even so, the possibility of modulating the results due to these differences in the instrument cannot be totally ruled out. Another potential weakness was that the price comparison was made not considering the weight of the product, but the portion available for purchase. The rationale behind the selection of this procedure was that consumers buy by the portion available.

As a strong point, we highlight the pioneering nature of this study in combining the analysis of variables and indicators of the food environment assessment in the framework of a university with 
the examination of the dynamics of this environment over time. Understanding how this environment is configured over time is fundamental for the development of interventions aimed at promoting a healthy UFE. Furthermore, data collection took place in the same months each year, thus avoiding that a potential difference could be due to food supply seasonal variations on campus.

\section{CONCLUSION}

In the three years of study, UFE did not favor healthy food choices. Although the UR appears as an important alternative, over time, the offer of ultra-processed items and their promotion have been frequent, together with the low supply of fresh or minimally processed foods and culinary preparations.

\section{CONTRIBUTORS}

AS FRANCO, PMP PEREZ, and IRR CASTRO participated in the conception, planning, analysis and interpretation of data and writing of the article and approved its final version. DS CANELLA participated in the analysis and interpretation of data and writing of the article and approved its final version. DH BANDONI participated in the conception, planning and writing of the article, and approved its final version.

\section{RE FERE N CES}

1. Roy R, Hebden L, Kelly B, De Gois T, Ferrone EM, Samrout M, et al. Description, measurement and evaluation of tertiary-education food environments. $\mathrm{Br} J$ Nutr. 2016;115(9):1598-606. https://doi.org/10.1017/ S0007114516000568

2. Roy R, Kelly B, Rangan A, Allman-Farinelli M. Food environment interventions to improve the dietary behavior of young adults in tertiary education settings: a systematic literature review. J Acad Nutr Diet. 2015;115(10):1647-81. https://doi.org/10.1016/j.jand.2015.06.380

3. Gálvez Espinoza P, Egaña Rojas D, Masferrer D, Cerda Rioseco R. Propuesta de un modelo conceptual para el estudio de los ambientes alimentarios en Chile. Rev Panam Salud Publica. 2017;41:e169. https://doi. org/10.26633/RPSP.2017.169

4. Castro IRR, Canella DS, Mendes LL, Messias GM, Rocha LL, Carmo AS. Ambiente alimentar organizacional. In: Pessoa MC, Mendes LL, Costa BVL. Ambiente alimentar: saúde e nutrição. Rio de Janeiro: Rubio [in press]; 2020.

5. Pulz IS, Martins PA, Feldman C, Veiros MB. Are campus food environments healthy? A novel perspective for qualitatively evaluating the nutritional quality of food sold at foodservice facilities at a Brazilian university. Perspect Public Health. 2017;137(2):122-35. https://doi.org/10.1177/1757913916636414

6. Barbosa R, Henriques P, Guerra H, Emerentino J, Soares D, Dias P, et al. Food environment of a Brazilian public university: challenges to promote healthy eating. Rev Chil Nutr. 2020;47(3):443-8. https://doi.org/10.4067/ S0717-75182020000300443

7. Caspi C, Sorensen G, Subramanian SV, Kawachi I. The local food environment and diet: a systematic review. Health Place. 2012;18:1172-87. https://doi.org/10.1016/j.healthplace.2012.05.006

8. Borges CA, Jaime PC. Development and evaluation of food environment audit instrument: AUDITNOVA. Rev Saúde Pública. 2019;53(91):1-16. https://doi.org/10.11606/s1518-8787.2019053001316

9. Duran ACFL, Lock K, Latorre MRDO, Jaime PC. Evaluating the use of in-store measures in retail food stores and restaurants in Brazil. Rev Saúde Pública. 2015;49:80. https://doi.org/10.1590/\$0034-8910.2015049005420

10. Franco AS. Ambiente alimentar universitário: caracterização, qualidade da medida e mudança no tempo [tese]. Rio de Janeiro: Universidade do Estado do Rio de Janeiro; 2016. 
11. Monteiro CA, Cannon G, Levy RB, Moubarac JC, Louzada ML, Rauber F, et al. Ultra-processed foods: what they are and how to identify them. Public Health Nutr. 2019;22(5):936-41. https://doi.org/10.1017/ S1368980018003762

12. Centers for Disease Control and Prevention. Epi Info. version 6.04 d. Atlanta; 2001.

13. International Business Machines Corporation. Statistical Package for the Social Sciences. IBM SPSS. version 21.0. New York: IBM Corp; 2012.

14. Bevan AL, Hartwell H, Hemingway A, Proença RPDC. An exploration of the fruit and vegetable "foodscape" in a university setting for staff: a preliminary study. Br Food J. 2015;117(1):37-49. https://doi.org/10.1108/ BFJ-06-2013-0153

15. Silva, M. Ações afirmativas no Brasil: considerações acerca das cotas raciais na universidade. Rev Pedagog. 2017;19(42):7-129. https://doi.org/10.22196/rp.v19i42.3998

16. Perez PMP, Castro IRR, Canella DS, Franco AS. Effect of implementation of a University Restaurant on the diet of students in a Brazilian public university. Ciênc Saúde Coletiva. 2019;24(6):2351-60. https://doi. org/10.1590/1413-81232018246.11562017 